\title{
SENGKETA PILIHAN KEPALA DESA DALAM SUATU KAJIAN UNDANG-UNDANG REPUBLIK INDONESIA NOMOR 6 TAHUN 2014 TENTANG DESA
}

\author{
Ahmad Husaini, Kadi Sukarna \\ Magister Hukum Universitas Semarang, Semarang
}

\begin{abstract}
ABSTRAK
Tujuan penelitian ini adalah untuk menganalisa sengketa pemilihan kepala desa. Undang-Undang Nomor 6 Tahun 2014 tentang Desa telah memberi pengaturan tentang Kepala Desa yang tertuang di Pasal 26 sampai dengan Pasal 47 yang menjelaskan kewenangan, hak dan kewajiban, tata cara pemilihan, pemberhentian Kepala Desa. Begitu pula di dalam Peraturan Pemerintah Nomor 43 Tahun 2014 tentang Peraturan Pelaksanaan Undang-Undang Nomor 6 Tahun 2014 tentang Desa terdapat pengaturan tentang Kepala Desa yakni mulai Pasal 40 sampai dengan 60 yang kurang lebih sama mengatur kewenangan, hak dan kewajiban, tata cara pemilihan, dan pemberhentian Kepala Desa namun peraturan-peraturan tersebut belum secara jelas mengatur bagaimana penyelesaian sengketa terkait terjadinya pemilihan dan pemberhentian kepala desa. Permasalahan dalam penelitian ini adalah Bagaimana penyelesaian sengketa pilihan kepala desa sesuai Undang-Undang Republik Indonesia Nomor 6 Tahun 2014 Tentang Desa dan Bagaimana solusi atas permasalahan Sengketa Pilihan Kepala Desa Suatu Kajian Undang-Undang Republik Indonesia Nomor 6 Tahun 2014 Tentang Desa. Metode dalam penelitian ini menggunakan metode penelitian deskriptif kualitatif dengan pendekatan yuridis normatif. Hasil penelitian ini adalah : (1) Model penyelesaian perselisihan pemilihan kepala desa yang mengedepankan musyawarah sesuai asas otonomi asli desa ini harus diterapkan oleh pemerintah. (2) Beberapa kendala yang muncul adalah: Pertama, timbulnya perselisihan pada jangka waktu terkait dengan pelaporan protes atau pengajuan keberatan terhadap penetapan hasil pemilihan kepala desa antara Undang-Undang No. 6 Tahun 2014 dengan Peraturan Bupati yang berlaku. Kedua, pada Undang-Undang No. 6 Tahun 2014 dijelaskan bahwa apabila terdapat perselisihan pemilihan kepala desa, Bupati/Walikota yang diberikan wewenang untuk menyelesaikan perselisihan pilkades tersebut. Namun hal tersebut kurang efektif karena Bupati/Walikota adalah jabatan politik. Solusinya apabila terjadi Perselisihan Pemilihan Kepala Desa (Pilkades) sebaiknya diatur dalam peraturan yang ada.
\end{abstract}

Kata kunci : sengketa; pilihan kepala desa; desa. 


\title{
ELECTION DISPUTE OF THE VILLAGE HEAD IN A STUDY ON LAW OF THE REPUBLIC OF INDONESIA NUMBER 6 OF 2014 CONCERNING VILLAGE
}

\author{
Ahmad Husaini, Kadi Sukarna \\ Master of Law, University of Semarang, Semarang
}

\begin{abstract}
The purpose of this study is to analyze the disputes over village head elections. According to Law Number 6 of 2014 concerning Villages has provided regulations regarding Village Heads as stipulated in Article 26 through Article 47 which explains the authority, rights and obligations, procedures for election, termination of the Village Head. Likewise, in Government Regulation Number 43 of 2014 concerning Regulations for Implementing Law Number 6 of 2014 concerning Villages, there are provisions concerning Village Heads, starting from Articles 40 to 60 which more or less regulate authority, rights and obligations, election procedures, and dismissal of the village head but the regulations do not clearly stipulate how the dispute resolution is related to the election and dismissal of the village head.The problem in this study is how is the dispute over the choice of the village head in a study of the Law of the Republic of Indonesia Number 6 of 2014 concerning Villages and How is the solution to the problem of the Dispute of the Choice of Village Heads in a Study of the Law of the Republic of Indonesia Number 6 of 2014 concerning the Village. The method in this study uses descriptive qualitative research methods with a normative juridical approach.

The results of this study are: (1) The model of resolving disputes over village head elections that prioritizes deliberations in accordance with the principle of original village autonomy must be applied by the government. (2) Some obstacles that arise are: First, the emergence of disputes in the period related to the reporting of protests or submitting objections to the determination of the results of the election of village heads between Law No. 6 of 2014 with applicable Regent Regulations. Secondly, in Law No. 6 of 2014 explained that if there were disputes over the election of village heads, the Regent / Mayor was given the authority to resolve the pilkades dispute. However, this is less effective because the Regent / Mayor is a political office. The solution if there is a Village Head Election Dispute (Pilkades) should be regulated in existing regulations.
\end{abstract}

Keywords: dispute; choice of village head; village. 


\section{A. PENDAHULUAN}

Indonesia merupakan sebuah negara kesatuan. Hal ini berdasarkan UndangUndang Dasar Negara Republik Indonesia Tahun 1945. Dalam UUD NKRI Tahun 1945 juga terdapat pengaturan bahwa Negara Kesatuan Republik Indonesia dibagi atas daerah provinsi, dan daerah provinsi itu dibagi atas kabupaten dan kota yang tiap-tiap provinsi, kabupaten, dan kota itu mempunyai pemerintahan daerah ${ }^{1}$.

Selanjutnya didalam tiap kabupaten atau kota tersebut terdapat satuan pemerintahan yang disebut desa dan kelurahan. Dasar pengaturan desa adalah Undang-Undang Dasar Negara Republik Indonesia Tahun 1945. UUD mengatur bahwa negara mengakui dan menghormati kesatuan-kesatuan masyarakat hukum adat beserta hak-hak tradisionalnya sepanjang masih hidup dan sesuai dengan perkembangan masyarakat dan prinsip Negara Kesatuan Republik Indonesia, serta mengamanatkan hal tersebut untuk diatur di dalam undang-undang ${ }^{2}$.

Sebagai bukti keberadaan desa atau yang disebut dengan nama lain sudah ada jauh sebelum Negara Indonesia terbentuk, penjelasan Pasal 18 Undang-Undang Dasar Negara Republik Indonesia Tahun 1945 sebelum amandemen menyebutkan bahwa:

"Dalam teritorial Negara Indonesia terdapat kurang lebih 250 zelfbesturende landschappen dan volksgemeenschappen, seperti desa di Jawa dan Bali, nagari di Minangkabau, dusun dan marga di Palembang dan sebagainya. Daerah-daerah itu mempunyai susunan asli, dan oleh karenanya dapat dianggap sebagai daerah yang bersifat istimewa."

Saat ini, desa dan kelurahan adalah dua satuan pemerintahan paling bawah (bukan kedudukannya) dengan status yang berbeda. Desa adalah satuan pemerintahan yang diberi hak otonomi adat sehingga merupakan badan hukum sedangkan kelurahan adalah satuan pemerintahan administrasi yang hanya merupakan kepanjangan tangan dari pemerintah kabupaten/kota.

Dalam melaksanakan kewenangan yang telah diberikan oleh Undang-Undang tersebut kepala desa memegang peranan yang sangat strategis. Ia merupakan

\footnotetext{
${ }^{1}$ Pasal 18 ayat (1) Undang-Undang Dasar Negara Republik Indonesia Tahun 1945.

${ }^{2}$ Pasal 18B ayat (2) Undang-Undang Dasar Negara Republik Indonesia Tahun 1945.
} 
pemeran utama dalam mewujudkan idealisme desa yang dimandatkan dalam Undang-Undang yakni menciptakan desa yang mandiri serta bermartabat.

Di dalam Undang-Undang Nomor 6 Tahun 2014 tentang Desa telah terdapat pengaturan tentang Kepala Desa yang tertuang di Pasal 26 sampai dengan Pasal 47 yang menjelaskan kewenangan, hak dan kewajiban, tata cara pemilihan, pemberhentian Kepala Desa. Begitu pula di dalam Peraturan Pemerintah Nomor 43 Tahun 2014 tentang Peraturan Pelaksanaan Undang-Undang Nomor 6 Tahun 2014 tentang Desa terdapat pengaturan tentang Kepala Desa yakni mulai Pasal 40 sampai dengan 60 yang kurang lebih sama mengatur kewenangan, hak dan kewajiban, tata cara pemilihan, dan pemberhentian Kepala Desa namun Peraturan Pemerintah Nomor 43 Tahun 2014 lebih bersifat teknis dan rinci karena merupakan peraturan pelaksana.

Titik awal berhasilnya roda pemerintahan dan pembangunan desa juga dimulai dari pemilihan Kepala Desa. Pemilihan Kepala Desa merupakan wujud demokrasi di desa. Demokrasi secara umum berarti pemerintahan dari, oleh, dan untuk rakyat ${ }^{3}$. Apabila proses pemilihan Kepala Desa yang sedang berlangsung telah selesai dilakukan mulai tahapan persiapan, pencalonan, pemungutan suara, hingga penetapan calon Kepala Desa terpilih ada pihak yang tidak puas atas hasil pemilihan Kepala Desa atau dengan kata lain terjadi sengketa atau perselisihan hasil pemilihan Kepala Desa maka diperlukan mekanisme penyelesaian dan lembaga atau institusi mana yang berwenang menyelesaikan sengketa tersebut.

Saat ini, memang terdapat pasal di dalam Undang-Undang Nomor 6 Tahun 2014 yang mengatur lembaga atau institusi mana yang berwenang menyelesaikan perselisihan hasil pemilihan Kepala Desa yakni Pasal 37 Ayat (5) dan Ayat (6) yang berbunyi:

Ayat 5

"Bupati/Walikota mengesahkan calon Kepala Desa terpilih sebagaimana dimaksud pada ayat (3) menjadi Kepala Desa paling lama 30 (tiga puluh) hari

3 Jimly Asshiddiqie, Hukum Tata Negara dan Pilar-Pilar Demokrasi, Sinar Grafika, Jakarta, 2012, hlm. 293. 
sejak tanggal diterimanya penyampaian hasil pemilihan dari panitia pemilihan Kepala Desa dalam bentuk keputusan Bupati/Walikota.”

Ayat 6

“ dalam hal terjadi perselisihan hasil pemilihan Kepala Desa, Bupati/Walikota wajib menyelesaikan perseisihan dalam jangka waktu sebagaimana dimaksud dalam ayat (5)"

Namun Ketentuan tersebut tidak diatur secara jelas bagaimana mekanismenya. Tidak jelasnya pengaturan dan tidak tepatnya lembaga yang berwenang dalam penyelesaian perselisihan hasil pemilihan Kepala Desa menimbulkan berbagai permasalahan. Turut campurnya Bupati/Walikota sangat tidak sesuai dengan asas otonomi asli yang dimiliki desa.

\section{B. PERMASALAHAN}

Berdasarkan latar belakang diatas, maka penulis dapat merumuskan masalah yang akan menjadi acuan dalam penelitian ini yaitu :

1. Bagaimana mekanisme penyelesaian sengketa pilihan kepala desa sesuai Undang-Undang Republik Indonesia Nomor 6 Tahun 2014 Tentang Desa?

2. Bagaimana solusi atas permasalahan sengketa Pilihan Kepala Desa Suatu Kajian Undang-Undang Republik Indonesia Nomor 6 Tahun 2014 Tentang Desa?

\section{METODE PENELITIAN}

Penelitian (research) merupakan upaya pencarian yang bernilai edukatif. Dengan demikian penelitian berangkat dari ketidaktahuan dan keraguan dan kemudian berakhir pada suatu kesimpulan dari permasalahan. ${ }^{4}$

Agar suatu penelitian dapat lebih lancar, teraran, dan lebih tertata, maka diperlukan suatu metode penelitian, karena pada, hakekatnya metode penelitian tersebut memberikan pedoman tentang cara-cara seseorang menganalisa, mempelajari, dan memahami lingkungan-lingkungan yang dihadapi. Metode adalah suatu unsur mutlak yang harus ada dalam penelitian dan pengembangan ilmu pengetahuan. Tanpa metode penelitian tidak mungkin seseorang akan dapat

\footnotetext{
${ }^{4}$ Amirudin, Pengantur Metode Penelitian Hukum, PT. Raja Grafindo Persada, Jakarta, 2004, hlm. 19.
} 
menganalisis, menemukan dan merumuskan suatu kebenaran mengenai sesuatu hal yang sedang ditelitinya secara runtut dan terarah. ${ }^{5}$

Selanjutnya untuk memperoleh bahan-bahan atau data-data yang diperlukan dalam penelitian ini, maka penulis menggunakan metode sebagai berikut:

\section{Metode Pendekatan}

Pada penelitian ini metode yang digunakan tidak mendasar angka-angka statistik tetapi terlebih pada pemahaman dan deskripsi secara normatif. Dengan demikian metode pendekatan yang digunakan dalam penelitian ini adalah metode kualitatif.

Menurut Bogdan dan Taylor sebagaimana yang dikutip oleh Lexi J. Moleong yang dimaksud dengan penelitian kualitatif adalah prosedur penelitian yang menggunakan data deskriptif berupa kata-kata tertulis atau lisan dari orangorang dan perilaku yang dapat diamati. ${ }^{6}$

Sehubungan dengan metode penelitian Soerjono Soekanto mengatakan bahwa: Pada penelitian dengan metode kualitatif akan dihasilkan data deskriptif analitis yaitu apa yang dinyatakan oleh informan secara tertulis atau lisan dan juga perilakunya yang nyata, yang diteliti dan di pelajari sebagai sesuatu yang utuh. $^{7}$

Penelitian ini dilakukan dengan meneliti data yang diperoleh dari penelitian lapangan dan bahan-bahan kepustakaan yang berhubungan dengan perumusan masalah yang telah ditetapkan. Penelitian hukum normatif setalu mengambil isu dari hukum sebagai sebagai norma yang digunakan untuk memberikan "justifikasi" perspesktif tentang suatu hukum. ${ }^{8}$

\section{Spesifikasi Penelitian}

Spesifikasi penelitian ini adalah deskriptif analitis. Penelitian ini berusaha menggambarkan dan menganalisis permasalahan berdasarkan peraturan perundang-undangan yang berlaku.

\footnotetext{
${ }^{5}$ Soerjano Soekanto, Pengantar Penelitian Hukum, Ul Press, Jakarta, 2005, hlm. 45.

${ }^{6}$ Lexy J. Moleong, Metodologi Penelitian Kualitatif, Remaja Rosdakarya, Bandung, 2002, hlm. 3.

${ }^{7}$ Soerjono Soekanto, Op.Cit., hlm. 32.

${ }^{8}$ Mukti Fajar ND dan Yulianto Achmad, Dualisme Penelitian Hukum Normatif \& Empihs, Pustaka Pelajar, Yogyakarta, 2013, hlm. 34.
} 


\section{Jenis dan Sumber Data}

Sehubungan dengan metode pendekatan dalam penelitian ini adalah yuridis normatif, maka penelitian ini dilakukan dengan studi pustaka yang bersumber pada data sekunder

Data sekunder yang merupakan sumber utama dalam penelitian ini dikumpulkan dengan melakukan studi kepustakaan/studi pusat dokumen. Data sekunder diperoleh di perpustakaan, pusat dokumentasi, arsip dan museum. ${ }^{9}$ Dengan demikian studi ini untuk mencari konsepsi-konsepsi, teori-teori, pendapat-pendapat dan penemuan-penemuan yang berhubungan dengan pokok permasalahan. ${ }^{10}$ Yakni tentang sengketa pilihan kepala desa dalam suatu kajian Undang-Undang Republik Indonesia Nomor 6 Tahun 2014 Tentang Desa.

\section{Metode Analisis Data}

Penelitian ini bersifat analitis kualitatif, yaitu menggambarkan, menjelaskan, serta menganalisis sejumlah data sekunder yang telah diperoleh. Penjelasan terhadap data dilakukan dengan menggunakan teori-teori dan normanorma hukum yang ada sedangkan keseluruhan data yang diperoleh disajikan secara kualitatif yaitu dalam bentuk uraian yang sistematis. ${ }^{11}$

\section{PEMBAHASAN}

\section{Penyelesaian Sengketa Pilihan Kepala Desa Sesuai Kajian Undang-Undang}

\section{Republik Indonesia Nomor 6 Tahun 2014 Tentang Desa}

Otonomi desa merupakan otonomi asli, bulat, dan utuh serta bukan merupakan pemberian dari pemerintah. Sebaliknya pemerintah berkewajiban menghormati otonomi asli yang dimiliki oleh desa. Sebagai kesatuan masyarakat hukum yang mempunyai susunan asli berdasarkan hak istimewa, desa dapat melakukan perbuatan

\footnotetext{
${ }^{9}$ Burhan Ashofa, Metode Penelitian Hukum. Rineka Cipta, Jakarta, hlm. 104.

${ }^{10}$ Rony Hanitijo Soemitro. Metode Penelitian Hukum dan Jumitri. Ghalia Indonesia, Yogyakarta, hlm. 98 .

${ }^{11}$ Soerjono Soekanto, Op. Cit, hlm. 25.
} 
hukum baik hukum publik maupun hukum perdata, memiliki kekayaan, harta benda, serta dapat dituntut dan menuntut di muka pengadilan. ${ }^{12}$

Dalam menghadapi permasalahan yang ada di dalam pemilihan kepala desa atau pasca pemilihan kepala desa (perselisihan hasil pemilihan kepala desa), penting untuk mendefinisikan letak pemilihan Kepala Desa termasuk ke dalam rezim hukum Pemilu atau bukan.

Penentuan rezim Pemilihan Kepala Desa ini akan berdampak pada penyelenggara Pemilihan Kepala Desa dan Lembaga mana yang berwenang menyelesaikan sengketa hasil pemilihan Kepala Desa. Berdasarkan Undang-Undang Nomor 6 Tahun 2014 tentang Desa, Pemilihan Kepala Desa ini tergolong ke dalam rezim Hukum Desa bukan rezim Hukum Pemilu. Hal ini dapat dilihat dari penyelenggara pemilihan Kepala Desa bukanlah Komisi Pemilihan Umum dan Lembaga Penyelesain Sengketa bukanlah Mahkamah Konstitusi.

Konstitusi Indonesia yaitu Undang-Undang Dasar Negara Republik Indonesia Tahun 1945 menyebutkan secara limitatif pemilihan apa saja yang termasuk ke dalam rezim Pemilihan Umum yakni di dalam Pasal 22E ayat (2):

"Pemilihan umum diselenggarakan untuk memilih anggota Dewan Perwakilan Rakyat, Dewan Perwakilan Daerah, Presiden dan Wakil Presiden dan Dewan Perwakilan Rakyat Daerah.”

Tidak terdapat frasa "Pemilihan Kepala Desa" di dalam penyelenggaraan Pemilihan Umum yang diatur di dalam Undang-Undang Dasar Negara Republik Indonesia Tahun 1945 tersebut. Pengaturan Desa diatur tersendiri di dalam Bab VI Undang-Undang Dasar Negara Republik Indonesia Tahun 1945 yakni tentang Pemerintahan Daerah bukan di dalam Bab VIIB tentang Pemilihan Umum. Mahkamah Konstitusi menekankan bahwa dalam memaknai rumusan UndangUndang Dasar Negara Republik Indonesia Tahun 1945 harus melihat makna teks, original intent, dan makna gramatikal yang komprehensif. Oleh karena itu Pasal 22E UUD NRI Tahun 1945 harus dimaknai secara limitatif bahwa pemilihan umum yang

12 Sutoro Eko, Kedudukan dan Kewenangan Desa, Forum Pengembangan Pembaharuan Desa (FFPD), Yogyakarta, 2014, hlm. 81. 
diselenggarakan adalah untuk memilih anggota DPR, DPD, Presiden dan Wakil Presiden serta DPRD dan dilaksanakan setiap lima tahun sekali. ${ }^{13}$

Pemilihan kepala desa diselenggarakan untuk memilih kepala desa, sedangkan pemilihan kepala daerah diselenggarakan untuk memilih kepala daerah. Untuk menentukan apakah kepala desa termasuk ke dalam pemilihan kepala daerah atau tidak, maka yang perlu dianalisis adalah kedudukan desa bisa disebut atau termasuk ke dalam daerah atau tidak. Pasal 1 angka 1 Undang-Undang Nomor 6 Tahun 2014 tentang Desa menyebutkan pengertian desa:

"Desa adalah desa dan desa adat atau yang disebut dengan nama lain, selanjutnya disebut Desa, adalah kesatuan masyarakat hukum yang memiliki batas wilayah yang berwenang untuk mengatur dan mengurus urusan pemerintahan, kepentingan masyarakat setempat berdasarkan prakarsa masyarakat, hak asal usul, dan/atau hak tradisional yang diakui dan dihormati dalam sistem pemerintahan Negara Kesatuan Republik Indonesia."

Sedangkan pengertian daerah yang dapat disebut sebagai daerah otonom dijelaskan di dalam Pasal 1 angka 12 Undang-Undang Nomor 23 Tahun 2014 tentang Pemerintahan Daerah sebagai berikut:

"Daerah Otonom yang selanjutnya disebut Daerah adalah kesatuan masyarakat hukum yang mempunyai batas-batas wilayah yang berwenang mengatur dan mengurus Urusan Pemerintahan dan kepentingan masyarakat setempat menurut prakarsa sendiri berdasarkan aspirasi masyarakat dalam sistem Negara Kesatuan Republik Indonesia."

Dari pengertian Desa dan Daerah di atas dapat kita ketahui perbedaan di antara keduanya. Desa maupun daerah sama-sama merupakan kesatuan masyarakat hukum. Kesatuan mayarakat hukum adalah organisasi kekuasaan atau organisasi pemerintahan. Namun daerah otonom sebagai kesatuan masyarakat hukum

13 Lihat Putusan Mahkamah Konstitusi Nomor 97/PUU-XI/2013 Perihal Uji Materiil Pasal 236C UndangUndang Nomor 12 Tahun 2008 tentang Perubahan Kedua atas Undang-Undang Nomor 32 Tahun 2004 tentang Pemerintahan Daerah dan Pasal 29 ayat (1) huruf e Undang-Undang Nomor 48 Tahun 2009 tentang Kekuasaan Kehakiman. 
berbentuk pemerintahan daerah yang terdiri dari kepala daerah dan Dewan Perwakilan Rakyat Daerah (DPRD). ${ }^{14}$

Jika melihat konstitusi yakni Undang-Undang Dasar Negara Republik Indonesia Tahun 1945 yang merupakan peraturan perundang-undangan tertinggi dalam hierarki peraturan peraturan perundang-undangan menyebutkan secara limitatif yang dikategorikan sebagai daerah. Di Dalam pasal 18 ayat (1) menyebutkan bahwa:

"Negara Kesatuan Republik Indonesia dibagi atas daerah-daerah propinsi dan daerah propinsi itu dibagi atas kabupaten dan kota, yang tiap-tiap propinsi, kabupaten, dan kota itu mempunyai pemerintahan daerah, yang diatur dengan undang-undang."

Selanjutnya di Pasal 18 ayat (2) menyebutkan bahwa:

"Pemerintahan daerah propinsi, daerah kabupaten, dan kota mengatur dan mengurus sendiri urusan pemerintahan menurut asas otonomi dan tugas pembantuan."

Dari rumusan pasal di dalam Undang-Undang Dasar Negara Republik Indonesia Tahun 1945 di atas, apabila melihat makna teks, original intent, dan makna gramatikal secara komprehensif maka Undang-Undang Dasar secara limitatif menyatakan bahwa yang bisa disebut sebagai daerah dalam sistem Negara Kesatuan Republik Indonesia hanyalah propinsi, kabupaten, dan kota. Dan ayat (2) menyebutkan bahwa pemerintahan daerah propinsi, kabupaten, dan kota ini mengatur dan mengurus urusan pemerintahan menurut asas otonomi dan tugas pembantuan. Hal ini jelas berbeda dengan pemerintahan desa yang mengandung unsur "prakarsa masyarakat, hak asal usul, dan/atau hak tradisional. ${ }^{15}$

Dalam sejarah pengaturan penyelesaian perselisihan hasil pemilihan kepala desa di Indonesia, belum ada undang-undang yang secara eksplisit mengatur mekanisme

\footnotetext{
${ }^{14}$ Sutoro Eko, Titik Istiyawatun Khasanah, Dyah Widuri, Suci Handayani, Ninik Handayani, Puji Qomariyah, Sahrul Aksa, Hastowiyono, Suharyanto, Borni Kurniawan, Op.Cit., hlm. 34.

${ }^{15}$ Pasal 18B ayat (1) dan (2) Undang-Undang Dasar Negara Republik Indonesia Tahun 1945.
} 
penyelesaian perselisihan hasil pemilihan kepala desa. Hanya ketika berlakunya Undang-Undang Nomor 32 Tahun 2004 tentang Pemerintahan Daerah, Peraturan pelaksananya yaitu Peraturan Pemerintah Nomor 72 Tahun 2005 tentang Desa mengamanatkan penyelesaian masalah terkait pemilihan kepala desa diatur dengan peraturan daerah. Pasal 53 ayat (1) diatur bahwa Ketentuan lebih lanjut mengenai Tata Cara Pemilihan, Pencalonan, Pengangkatan, Pelantikan, dan Pemberhentian Kepala Desa diatur dengan Peraturan Daerah Kabupaten/ Kota. ${ }^{16}$ Di ayat (2) disebutkan bahwa Peraturan Daerah Kabupaten/Kota sebagaimana dimaksud pada ayat (1), sekurang-kurangnya memuat berbagai macam hal, salah satunya adalah mekanisme pengaduan dan penyelesaian masalah. ${ }^{17}$

Jangka waktu penyelesaian perselihan hasil pemilihan Kepala Desa ini adalah 30 hari sejak tanggal diterimanya penyampaian hasil pemilihan dari panitia pemilihan Kepala Desa. Hal ini diatur di dalam Pasal 37 ayat (5) Undang-Undang Nomor 6 Tahun 2014 yakni:

(5) Bupati / Walikota mengesahkan calon Kepala Desa terpilih sebagaimana dimaksud pada ayat (3) menjadi Kepala Desa paling lama 30 (tiga puluh) hari sejak tanggal diterimanya penyampaian hasil pemilihan dari panitia pemilihan Kepala Desa dalam bentuk keputusan Bupati/Walikota.

Berdasarkan ketentuan inilah maka penyelesaian sengketa hasil Pemilihan Kepala Desa menjadi kewajiban bagi Bupati/Walikota apabila hal tersebut terjadi di daerah mereka. Mengingat ketentuan di dalam Undang-Undang Nomor 6 Tahun 2014 tentang Desa hanya mengatur secara singkat dan tidak merinci mekanisme penyelesaian sengketa hasil pemilihan Kepala Desa maka diaturlah ke dalam peraturan pelaksana.

Di dalam Peraturan Pemerintah Nomor 43 Tahun 2014 tentang Peraturan Pelaksanaan Undang-Undang Nomor 6 Tahun 2014 tentang Desa lagi-lagi belum

${ }^{16}$ Pasal 53 ayat (1) Peraturan Pemerintah Nomor 72 Tahun 2005 tentang Desa (Lembaran Negara Tahun 2005 Nomor 158, Tambahan Lembaran Negara Nomor 4587).

17 Pasal 53 ayat (2) Peraturan Pemerintah Nomor 72 Tahun 2005 tentang Desa (Lembaran Negara Tahun 2005 Nomor 158, Tambahan Lembaran Negara Nomor 4587) 
mengatur secara rinci bagaimana mekanisme penyelesaian perselisihan hasil Pemilihan Kepala Desa. Peraturan Pemerintah Nomor 43 Tahun 2014 hanya mengatur mengenai jangka waktu penyelesaian dan lembaga mana yang memiliki kewenangan untuk menyelesaikannya. Ketentuan ini terdapat di dalam Pasal 41 ayat (7) yakni:

"Dalam hal terjadi perselisihan hasil pemilihan kepala Desa, bupati/walikota wajib menyelesaikan perselisihan dalam jangka waktu 30 (tiga puluh) Hari”

Ketentuan ini jelas belum mewadahi proses penyelesaian perselisihan hasil pemilihan Kepala Desa. Dan Pasal 46 Peraturan Pemerintah Nomor 43 Tahun 2014 menyebutkan bahwa "Ketentuan lebih lanjut mengenai pemilihan Kepala Desa diatur dengan Peraturan Menteri”. Namun hingga saat ini belum ada Peraturan Menteri tentang pemilihan Kepala Desa.

Penyelesaian perselisihan hasil pemilihan kepala desa di dalam Undang-Undang Nomor 6 Tahun 2014 tentang Desa Di dalam Peraturan Pemerintah Nomor 43 Tahun 2014 tentang Peraturan Pelaksanaan Undang-Undang Nomor 6 Tahun 2014 tentang Desa dan nanti beserta peraturan-peraturan pelaksananya ini dilakukan di luar pengadilan (diselesaikan oleh bupati/walikota) atau lebih dikenal dengan alternatif penyelesaian sengketa (alternative dispute resolution).

Di Indonesia istilah ADR (alternative dispute resolution) relatif baru dikenal, tetapi sebenarnya penyelesaian-penyelesaian sengketa secara konsensus sudah lama dilakukan oleh masyarakat yang intinya menekankan pada upaya musyawarah mufakat, kekeluargaan, perdamaian, dan sebagainya. ${ }^{18}$

Didalam pasal 1 angka 10 Undang-Undang Nomor 30 Tahun 1999 tentang Arbitrase dan Alternatif Penyelesaian Sengketa mendefinisikan:

"Alternatif Penyelesaian Sengketa adalah lembaga penyelesaian sengketa atau beda pendapat melalui prosedur yang disepakati para pihak, yakni penyelesaian

\footnotetext{
18 Sophar Maru Hutagalung, Praktik Peradilan Perdata dan Alternatif Penyelesaian Sengketa, Sinar
} Grafika, Jakarta, 2012, hlm. 311. 
di luar pengadilan dengan cara konsultasi, negosiasi, mediasi, konsiliasi, atau penilain ahli."

Pengertian di atas mengandung unsur yang terpenting adalah "prosedur yang disepakati para pihak". Di dalam penyelesaian perselisihan hasil pemilihan kepala desa, para pihak terpaksa harus menyelesaikan sengketa kepada bupati/walikota karena telah diatur di dalam undang-undang. Padahal independensi bupati/walikota patut dipertanyakan dan para pihak belum tentu sepakat untuk menyelesaikan sengketa di muka bupati/walikota.

Sebagai penyelenggara pemerintahan yang dapat diusung oleh partai politik, peran bupati/walikota dalam penyelesaian perselisihan hasil pemilihan kepala desa dikhawatirkan akan menimbulkan kepentingan yakni calon yang dimenangkan adalah calon yang memiliki koneksi dengan bupati/walikota dengan harapan politik balas budi. Kekuasaan koneksi adalah kekuasaan yang timbul karena hubungan yang dijalin dengan orang-orang yang berpengaruh, baik di luar maupun di dalam organisasi. ${ }^{19}$

Akibat diselesaikan oleh bupati/walikota, dalam kasus seperti yang telah disebutkan di latar belakang, bupati/walikota menerbitkan Surat Keputusan tentang Pengesahan Calon Kepala Desa Terpilih. Hal ini dilakukan meskipun perselisihan hasil pemilihan kepala desa belum benar-benar selesai. Akibatnya Surat Keputusan tersebut digugat oleh calon yang kalah ke Pengadilan Tata Usaha Negara (PTUN). Sebagaimana kita ketahui bahwa di PTUN menggunakan acara pemeriksaan biasa, apabila dalam waktu 30 (tiga puluh) hari setelah dikeluarkannya Surat Keputusan Bupati/Walikota belum ada putusan pengadilan yang telah memperoleh kekuatan hukum tetap, dapat menimbulkan kekosongan jabatann kepala desa.

Sebagaimana diatur di dalam Pasal 40 ayat (3) dan (4) Peraturan Pemerintah Nomor 43 Tahun 2014 tentang Peraturan Pelaksanaan Undang-Undang Nomor 6 Tahun 2014 tentang Desa, bahwa apabila dalam pemilihan kepala desa serentak terjadi kekosongan jabatan kepala desa, maka bupati/walikota menunjuk penjabat

${ }^{19}$ J. Kaloh, Kepemimpinan Kepala Daerah: Pola Kegiatan, Kekuasaan, dan Perilaku Kepala Daerah dalam Pelaksanaan Otonomi Daerah, Sinar Grafika, Jakarta, 2009, hlm. 122. 
kepala desa dari unsur Pegawai Negeri Sipil (PNS) di lingkungan pemerintah kabupaten/kota. Pasal 40 ayat (3) dan (4) berbunyi sebagai berikut:

“(3) Dalam hal terjadi kekosongan jabatan kepala Desa dalam penyelenggaraan pemilihan kepala Desa serentak, bupati/walikota menunjuk penjabat kepala Desa. (4) Penjabat kepala Desa sebagaimana dimaksud pada ayat (3) berasal dari pegawai negeri sipil di lingkungan pemerintah daerah kabupaten/kota." ${ }^{20}$

Pemilihan kepala desa diselenggarakan untuk memilih kepala desa agar sesuai dengan aspirasi masyarakat desa, kekosongan jabatan yang diisi oleh penjabat kepala desa dari unsur PNS oleh bupati/walikota jelas bukan aspirasi masyarakat desa dan dapat menimbulkan penolakan atau permasalahan.

Yang paling penting dalam penyelesaian perselisihan hasil pemilihan kepala desa adalah lembaga mana yang berwenang menyelesaiakannya, bukan adanya intervensi atau turut campur pemerintah daerah kabupaten/kota sebagai lembaga yang menyelesaikan. Hal ini tentu tidak sesuai dengan asas otonomi asli sebagaimana termaktub di dalam Undang-Undang Dasar Negara Republik Indonesia di mana negara menghormati dan mengakui hak asal-usul masyarakat adat dalam hal ini desa. ${ }^{21}$

Beberapa kajian menunjukkan demokrasi mempunyai akar dalam tradisi lokal. Hal ini sesuai dengan pandangan "teori demokrasi ideal normatif" yang salah satu penganutnya adalah Mohammad Hatta, dengan merefleksikan kondisi pedesaan di Jawa pada kurun waktu pasca revolusi kemerdekaan hingga 1960-an. Ia berpendapat:

"Demokrasi asli letaknya di desa, sebagai entitas pemerintahan yang langsung berhubungan dengan rakyat. Ciri-ciri demokrasi desa menurut Hatta adalah pertama, rapat (tempat rakyat bermusyawarah dan bermufakat); kedua, hak rakyat untuk mengadakan protes; ketiga, citacita tolong menolong." 22

20 Pasal 40 ayat (3) dan (4) Peraturan Pemerintah Nomor 43 Tahun 2014 tentang Peraturan Pelaksanaan Undang-Undang Nomor 6 Tahun 2014 tentang Desa (Lembaran Negara Tahun 2014 Nomor 123, Tambahan Lembaran Negara Nomor 5539)

${ }^{21}$ Pasal 18B ayat (1) dan (2) Undang-Undang Dasar Negara Republik Indonesia Tahun 1945.

22 Ibid, hlm. 39. 
Pemikiran komunitarianisme itu sangat memengaruhi cara pandang pendiri negara Indonesia yakni Muhammad Hatta dalam melihat demokrasi lokal. Di desadesa sistem yang demokratis masih kuat dan hidup sehat sebagai bagian adat-istiadat yang hakiki, dasarnya adalah pemilikan tanah yang komunal yaitu setiap orang merasa bahwa ia harus bertindak berdasarkan persetujuan bersama, sewaktu menyelenggarakan kegiatan ekonomi. ${ }^{23}$

Demokrasi membutuhkan musyawarah karena tiga alasan: ${ }^{24}$ (1) memungkinkan warga mendiskusikan isu-isu publik dan membentuk opini; (2) memberikan pemimpin demokratis wawasan yang lebih baik mengenai isu-isu publik ketimbang yang harus dilakukan oleh pemilihan umum; (3) memungkinkan warga memberikan justifikasi pandangan mereka sehingga kita bisa mengidentifikasi pilihan yang baik dan yang buruk.

Konsep kemandirian desa yang diusung oleh Undang-Undang Nomor 6 Tahun 2014 tentang desa seperti dijelaskan di dalam Bab Tinjauan Pustaka di atas yang menyatakan bahwa kemandirian desa tentu tidak berdiri sendiri, tetapi sangat penting melihat relasi antara desa dengan pemerintah (negara), termasuk memperhatikan pendekatan pemerintah terhadap desa. Kehadiran negara terhadap desa seharusnya bukan sebagai sebuah intervensi, campur tangan, bahkan pemaksaan kehendak yang akan melemahkan otonomi asli desa. Tetapi apabila negara tidak hadir juga bukan hal yang tepat. Negara dalam memaknai desa harusnya memberikan fasilitas seperti di dalam konstitusi yaitu penghormatan dan pengakuan. Hal ini dilakukan negara melalui pembuatan peraturan perundang-undangan yang memperkuat otonomi asli.

Emansipasi lokal membutuhkan pengakuan (rekognisi) oleh negara, dan negara perlu mengambil langkah fasilitasi terhadap berbagai institusi lokal. ${ }^{25}$ Oleh karena itu dalam penyelesaian perselisihan hasil pemilihan kepala desa, pemerintah (negara) perlu memfasilitasi dengan dasar hukum dalam perundang-undangan yang mengatur dan mengakui musyawarah desa sebagai mekanisme pertama dan utama

\footnotetext{
${ }^{23}$ Sutoro Eko, Titik Istiyawatun Khasanah, Dyah Widuri, Suci Handayani, Ninik Handayani, Puji Qomariyah, Sahrul Aksa, Hastowiyono, Suharyanto, Borni Kurniawan, Op.Cit., hlm. 151.

${ }^{24}$ Ibid, hlm. 155.

${ }^{25}$ Sutoro Eko, Op.Cit., hlm. 83.
} 
penyelesaian perselisihan hasil pemilihan kepala desa. Dengan demikin relasi negara dan desa dapat terbentuk dan demokrasi lokal semakin kuat.

Masyarakat saat ini dihadapkan pada berbagai pilihan penyelesaian konflik atau sengketa, sesuai dengan tingkat kepentingan dan pemenuhan kebutuhan dasarnya dalam memandang konflik atau sengketa itu sendiri. ${ }^{26}$ Namun penyelesaian perselisihan hasil pemilihan kepala desa merupakan perselisihan yang terjadi di kalangan masyarakat desa. Masyarakat desa memiliki mekanisme penyelesaian perselisihan sendiri yaitu musyawarah.

Model penyelesaian perselisihan hasil pemilhan kepala desa adalah gambaran sederhana yang menunjukkan bagaimana aktivitas untuk mewujudkan dan memperkuat otonomi asli desa. model ini dimaksudkan untuk mengembalikan otonomi asli desa sesuai dengan seharusnya yang diamanatkan Undang-Undang Dasar Negara Republik Indonesia Tahun 1945.

Seperti diuraikan di atas, bahwa untuk menciptakan kepastian hukum dalam penyelesaian perselisihan hasil pemilihan kepala desa, mekanisme musyawarah perlu diberi jangka waktu. Apabila dalam jangka waktu 7 (tujuh) hari perselisihan masih belum menemui kesepakatan damai maka dapat dilakukan upaya penunjukan pihak ketiga yang netral.

Berbeda dengan penyelesaian perselisihan oleh bupati/walikota sebagaimana diatur dalam Undang-Undang Nomor 6 Tahun 2014 tentang Desa yang menggunakan upaya mediasi oleh bupati/walikota dalam bentuk keterpaksaan para pihak. Model perselisihan hasil pemilihan kepala desa yang menurut penulis harus diterapkan adalah sebuah kesepakatan para pihak untuk menunjuk pihak ketiga sebagai mediator yang netral. Para pihak bersepakat untuk bekerjasama dengan pihak ketiga atau pihak luar yang tidak memihak (imparsial) dalam proses negosiasi pemecahan sengketa. Penyelesaian model ini juga memiliki potensi untuk tidak tercapainya kesepakatan dan perlu dibatasi yakni 7 (tujuh) hari sejak upaya musyawarah tidak mencapai kesepakatan.

\footnotetext{
${ }^{26}$ Rachmad Syafa'at, Advokasi dan Pilihan Penyelesaian Sengketa: Latar Belakang, Konsep, dan Impementasinya, Agritek YPN, Malang, 2006, hlm. 33.
} 
Pembentukan lembaga peradilan yang berwenang menyelesaikan perselisihan hasil pemilihan kepala desa yang diatur secara jelas bagaimana mekanisme penyelesaian perselisihannya diharapkan mampu menciptakan keadilan dalam masyarakat dan proses demokrasi di desa. Pengajuan permohonan kepada pengadilan khusus merupakan alternatif kedua setelah mekanisme utama yakni musyawarah dan mekanisme alternatif pertama melalui penunjukan pihak ketiga yang netral tidak mencapai kata sepakat.

Upaya mewujudkan keadilan yang dalam penyelesaian perselisihan hasil pemilihan kepala desa ini diperankan oleh kamar Ad Hoc pengadilan negeri sebagai pemutus perselisihan hasil pemilihan kepala desa dan sebelumnya adalah payung hukum musyawarah di antara para pihak yang berselisih sebelum dibawa ke pengadilan apabila musyawarah tersebut tidak menghasilkan kata sepakat.

Pembentukan Pengadilan Khusus Perselisihan Hasil Pemilihan Kepala Desa adalah soal efisiensi dalam pembentukan dan dalam berlangsungnya persidangan. Keberadaan Pengadilan Khusus Perselisihan Hasil Pemilihan Kepala Desa harus dipahami hanya bersifat ad hoc dan khusus. Bersifat ad hoc karena hanya dibentuk dan bekerja ketika pelaksanaan pemilihan kepala desa serentak (pemilihan kepala desa serentak dapat dilaksanakan secara bergelombang tergantung kabupaten/kota bersangkutan). Setelah tahapan pemilihan kepala desa berakhir, maka berakhir juga masa kerja Pengadilan Khusus Perselisihan Hasil Pemilihan Kepala Desa. bersifat khusus karena hanya menangani sengketa hasil pemilihan kepala desa. Jadi dengan desain sebagai pengadilan ad hoc dan khusus, maka dapat dihindari kesan adanya penambahan lembaga baru dan tambahan biaya yang besar. ${ }^{27}$

Pengadilan Khusus Perselisihan Hasil Pemilihan Kepala Desa berkedudukan di Pengadilan Negeri yang daerah hukumnya berada di kabupaten/kota. Kedudukan Pengadilan Khusus Perselisihan Hasil Pemilihan Kepala Desa yang berada di Pengadilan Negeri mengingat jumlah desa yang sangat banyak. Hal ini juga akan memudahkan bagi setiap desa apabila calon kepala desanya yang merasa dirugikan

${ }^{27}$ Irvan Mawardi, Dinamika Sengketa Hukum Administrasi di Pemilukada (Mewujudkan Electoral Justice dalam Kerangka Negara Hukum Demokratis), Rangkang Education, Yogyakarta, 2014, hlm. 244. 
atas penetapan panitia pemilihan kepala desa mengenai hasil pemilihan kepala desa untuk mengajukan permohonan perselisihan hasil pemilihan kepala desa karena letak desa mereka yang tidak terlalu jauh dengan Pengadilan Negeri yang luas daerah hukumnya hanya wilayah kabupaten/kota.

Penulis mengajukan gagasan di dalam penyelesaian perselisihan hasil pemilihan kepala desa melalui Pengadilan Khusus terdapat tenggang waktu (daluarsa). Tenggang waktu tersebut adalah batasan waktu dalam mengajukan permohonan dan batasan waktu bagi hakim ad hoc Pengadilan Khusus Perselisihan Hasil Pemilihan Kepala Desa untuk memutus perkara. Tenggang waktu dalam mengajukan permohonan perselisihan hasil pemilihan kepala desa adalah 3 (tiga) hari sejak tanggal penyelesaian perselisihan dengan bantuan pihak ketiga yang netral tidak menghasilkan kesepakatan damai atau dengan kata lain 17 (tujuh belas) hari sejak tanggal penetapan calon kepala desa terpilih oleh Panitia Pemilihaan Kepala Desa. Sedangkan tenggang waktu perselisihan diputus oleh hakim ad hoc adalah paling lama 14 (empat belas) hari sejak tanggal diterimanya permohonan.

Putusan Pengadilan Khusus Perselisihan Hasil Pemilihan Kepala Desa yang bersifat final dan mengikat. Pengadilan Khusus Perselisihan Hasil Pemilihan Kepala Desa merupakan pengadilan tingkat pertama dan terakhir sebagai lembaga peradilan yang berwenang memutus perselisihan hasil pemilihan kepala desa. Karena tidak ada upaya hukum lagi, maka putusan Pengadilan Khusus Perselisihan Hasil Pemilihan Kepala Desa mempunyai kekuatan hukum tetap sejak putusan tersebut dibacakan di persidangan.

\section{Kendala Dan Solusi-Solusi Sengketa Pilihan Kepala Desa Suatu Kajian Undang-Undang Republik Indonesia Nomor 6 Tahun 2014 Tentang Desa}

Urgensi Pemilihan Umum Kepala Desa secara konseptual sangat erat terkait dengan upaya untuk mewujudkan tujuan yang hakiki dari adanya otonomi pemerintahan desa itu sendiri yang merupakan kesatuan masyarakat hukum yang diakui keberadaannya dalam wilayah NKRI, yaitu terciptanya pemerintahan desa yang demokratis dan terwujudnya kesejahteraan masyarakat desa, yang secara 
historis bahwa Pilkada merupakan prototype Pemilihan Umum langsung di Indonesia. Tetapi dalam perjalanannya justru Pilkades menjadi sistem pemilihan yang paling statis dan tradisional seakan menjadi anak tiri dalam kesatuan sistem pemilihan di Indonesia.

Selama ini suksesi Pemilihan Kepala Desa (Pilkades) tidak pernah kering dari pembicaraan dari mulut ke mulut, dari pena ke pena, dan dari otak ke otak. Hal ini mengingat karena pemilihan kepala desa adalah refleksi bagaimana demokrasi di Indonesia ini coba diimplementasikan. Disisi lain pemilihan kepala merupakan sarana sirkulasi elit dan transfer kekuasaan ditingkat lokal. Dalam konteks ini Pemilihan Kepala Desa diharapkan secara langsung membuat masyarakat mengerti akan hak dan kewajibannya. Karena Pemilihan Kepala Desa adalah momen dimana masyarakat mengerti posisi mereka sebagai warga dalam peraturan politik di desa tersebut yang terjadi proses interaksi antara rakyat dan pemerintah sebagai wujud adanya demokrasi dari rakyat, oleh rakyat, dan untuk rakyat.

Berkaitan dengan Pemilihan Kepala Desa, munculnya berbagai reaksi masyarakat setelah Pemilihan Kepala Desa di daerah-daerah merupakan wujud adanya peningkatan partisipasi atau kepedulian masyarakat terhadap desanya. Namun disisi lain hal tersebut menunjukkan bahwa mekanisme pemilihan kepala desa selama ini masih diwarnai dengan kecurangan. Kecurangan-kecurangan tersebut memicu sengketa-sengketa Pemilihan Kepala Desa yang harus diselesaikan. Namun sayangnya dalam Undang-Undang No. 6 Tahun 2014 tentang Desa dan bahkan Peraturan Daerah No. 4 Tahun 2017 tentang Pilkades maupun Peraturan Bupati No. 37 Tahun 2014 tentang Pilkades dan peraturan pemerintah lainnya yang terkait belum mengatur secara khusus tentang penyelesaian sengketa pilkades. Hal ini memunculkan kendala dalam penyelesaiannya.

Beberapa kendala yang muncul adalah: Pertama, timbulnya perselisihan pada jangka waktu terkait dengan pelaporan protes atau pengajuan keberatan terhadap penetapan hasil pemilihan kepala desa antara Undang-Undang No. 6 Tahun 2014 dengan Peraturan Bupati yang berlaku. Kedua, pada Undang-Undang No. 6 Tahun 2014 dijelaskan bahwa apabila terdapat perselisihan pemilihan kepala desa, 
Bupati/Walikota yang diberikan wewenang untuk menyelesaikan perselisihan pilkades tersebut. Namun hal tersebut kurang efektif karena Bupati/Walikota adalah jabatan politik dan setiap Pemilihan Umum Kepala Daerah (Pemilukada) membutuhkan suara untuk maju kembali menjadi Bupati/Walikota dan dapat mengganggu demokrasi di Indonesia.

Seharusnya penyelesaian perselisihan Pemilihan Kepala Desa (Pilkades) diselesaikan oleh lembaga yudikatif, dan merivisi Undang-Undang No. 6 Tahun 2014 tentang Desa terutama pada Pasal 37 ayat 6 untuk penyelesaian perselisihan Pemilihan Kepala Desa (Pilkades) dengan memberikan kewenangan kepada lembaga Yudikatif yang sebelumnya diberikan kepada Bupati/Walikota, atau dibuatkan "Peradilan Khususee sebagai lembaga diluar Yudikatif, asalkan pembentuk UndangUndang menetapkan hal tersebut. Dibeberapa negara peradilan khusus itu dapat dilakukan oleh lembaga diluar Mahkamah Agung (MA) maupun Mahkamah Konstitusi (MK), oleh sebab itu kita dapat menyerahkan peradilan itu kepada sebuah lembaga quasi peradilan seperti Bawaslu asalkan diberikan wewenang yang tegas oleh Undang-Undang sehingga penyelesaian perselisihan Pemilihan Kepala Desa diselesaikan diluar eksekutif. Menurut Penulis Penyelesaian perselisihan Pemilihan Kepala Desa (Pilkades) diluar eksekutif lebih efektif karena tidak adanya kepentingan politik atau intervensi dalam penyelesaian Perselisihan Pemilihan Kepala Desa.

\section{B. PENUTUP}

Undang-Undang Nomor 6 Tahun 2014 tentang Desa telah memberi pengaturan tentang Kepala Desa yang tertuang di Pasal 26 sampai dengan Pasal 47 yang menjelaskan kewenangan, hak dan kewajiban, tata cara pemilihan, pemberhentian Kepala Desa. Begitu pula di dalam Peraturan Pemerintah Nomor 43 Tahun 2014 tentang Peraturan Pelaksanaan UndangUndang Nomor 6 Tahun 2014 tentang Desa terdapat pengaturan tentang Kepala Desa yakni mulai Pasal 40 sampai dengan 60 yang kurang lebih sama mengatur kewenangan, hak dan kewajiban, tata cara pemilihan, dan pemberhentian Kepala Desa namun peraturan-peraturan tersebut belum 
secara jelas mengatur bagaimana penyelesaian sengketa terkait terjadinya pemilihan dan pemberhentian kepala desa. Model penyelesaian perselisihan pemilihan kepala desa yang mengedepankan musyawarah sesuai asas otonomi asli desa ini harus diterapkan oleh pemerintah.

Beberapa kendala yang muncul adalah: Pertama, timbulnya perselisihan pada jangka waktu terkait dengan pelaporan protes atau pengajuan keberatan terhadap penetapan hasil pemilihan kepala desa antara Undang-Undang No. 6 Tahun 2014 dengan Peraturan Bupati yang berlaku. Kedua, pada UndangUndang No. 6 Tahun 2014 dijelaskan bahwa apabila terdapat perselisihan pemilihan kepala desa, Bupati/Walikota yang diberikan wewenang untuk menyelesaikan perselisihan pilkades tersebut. Namun hal tersebut kurang efektif karena Bupati/Walikota adalah jabatan politik. Solusinya apabila terjadi Perselisihan Pemilihan Kepala Desa (Pilkades) sebaiknya diatur dalam peraturan yang ada. 


\section{DAFTAR PUSTAKA}

\section{BUKU}

Amirudin, Pengantur Metode Penelitian Hukum, PT. Raja Grafindo Persada, Jakarta, 2004.

Burhan Ashofa, Metode Penelitian Hukum. Rineka Cipta, Jakarta.

J. Kaloh, Kepemimpinan Kepala Daerah: Pola Kegiatan, Kekuasaan, dan Perilaku Kepala Daerah dalam Pelaksanaan Otonomi Daerah, Sinar Grafika, Jakarta, 2009.

Jimly Asshiddiqie, Hukum Tata Negara dan Pilar-Pilar Demokrasi, Sinar Grafika, Jakarta, 2012.

Lexy J. Moleong, Metodologi Penelitian Kualitatif, Remaja Rosdakarya, Bandung, 2002.

Mukti Fajar ND dan Yulianto Achmad, Dualisme Penelitian Hukum Normatif \& Empihs,

Pustaka Pelajar, Yogyakarta, 2013.

Rachmad Syafa'at, Advokasi dan Pilihan Penyelesaian Sengketa: Latar Belakang, Konsep, dan Impementasinya, Agritek YPN, Malang, 2006.

Rony Hanitijo Soemitro. Metode Penelitian Hukum dan Jumitri. Ghalia Indonesia, Yogyakarta.

Soerjano Soekanto, Pengantar Penelitian Hukum, Ul Press, Jakarta, 2005.

Sophar Maru Hutagalung, Praktik Peradilan Perdata dan Alternatif Penyelesaian Sengketa, Sinar Grafika, Jakarta, 2012.

Sutoro Eko, Kedudukan dan Kewenangan Desa, Forum Pengembangan Pembaharuan Desa (FFPD), Yogyakarta, 2014. 